\title{
31. ROCK MAGNETIC PROPERTIES OF HYDROTHERMALLY FORMED IRON SULFIDES FROM MIDDLE VALLEY, JUAN DE FUCA RIDGE ${ }^{1}$
}

\author{
Ulrike Körner ${ }^{2}$
}

\begin{abstract}
Hydrothermally formed sulfide samples recovered from the Juan de Fuca Ridge during Ocean Drilling Program Leg 139 were investigated to determine the carrier of remanent magnetization and to study rock magnetic properties. The samples were examined by isothermal remanent magnetization acquisition, alternating field demagnetization, back field measurements, thermomagnetic and hysteresis measurements, X-ray diffraction, and ore microscopy. Grain sizes for magnetite and pyrrhotite particles were estimated from hysteresis parameters on samples containing only one magnetic phase. Magnetomineralogical analyses made on whole-rock samples show that massive sulfides recovered from Holes $856 \mathrm{G}$ and $856 \mathrm{H}$ are composed predominantly of pyrite, pyrrhotite, magnetite, and minor amounts of sphalerite and chalcopyrite. Magnetite together with two types of pyrrhotite determines the magnetic properties of these rock samples. The first type of pyrrhotite is ferrimagnetic up to $320^{\circ} \mathrm{C}$. X-ray diffraction data are in good agreement with those for monoclinic pyrrhotite. The second type of pyrrhotite is antiferromagnetic at room temperature and ferrimagnetic between $200^{\circ} \mathrm{C}$ and $270^{\circ} \mathrm{C}$. X-ray diffraction data show typical peaks for hexagonal pyrrhotite. Thermomagnetic analyses indicate that samples from Hole $856 \mathrm{G}$ contain mainly magnetite, whereas parameters from Hole $856 \mathrm{H}$ were also influenced by pyrrhotite. Pyrrhotite and magnetite were distinguished by the large $\mathrm{J}_{\mathrm{rs}} / \mathrm{J}_{\mathrm{s}}$ and the small $\mathrm{B}_{\mathrm{cr}} / \mathrm{B}_{\mathrm{c}}$ ratios for pyrrhotite compared with those for magnetite, and through direct methods such as ore microscopy and X-ray diffraction.
\end{abstract}

\section{INTRODUCTION}

The sedimented spreading center at the northern end of the Juan de Fuca Ridge provides ideal conditions for creating sulfides because the relatively impermeable sediment limits the recharge and discharge of hydrothermal fluids and thermally insulates the underlying crust. Where discharge of hydrothermal fluids does occur, large sulfide deposits can be produced (Davis, Mottl, Fisher, et al., 1992). Three well-studied sediment-covered spreading centers are located in the Eastern Pacific Ocean: Middle Valley on the Juan de Fuca Ridge, Escanaba Trough on the Gorda Ridge, and Guaymas Basin in the Gulf of California. High-temperature hydrothermal discharge and sulfide deposits have been observed and sampled at all three locations (Lonsdale and Becker, 1985; Davis et al., 1987; Koski et al., 1988). Ocean Drilling Program (ODP) Site 856 is located in the eastern part of Middle Valley $\left(48^{\circ} 26^{\prime} \mathrm{N}, 128^{\circ} 41^{\prime} \mathrm{W}\right)$ and comprises a transect of holes extending from the top of a small, sediment-covered hill southward to a low ridge of massive sulfide, which protrudes $60 \mathrm{~m}$ above the surrounding seafloor. The investigated samples from Holes $856 \mathrm{G}$ and $856 \mathrm{H}$ contain predominantly magnetite and pyrrhotite as magnetic phases. Pyrrhotite rarely has been found to carry a useful paleomagnetic record of the ancient geomagnetic field, but the strong ferrimagnetism, high susceptibility, and high electrical conductivity of pyrrhotite and its common occurrence in sulfide ore deposits make the mineral of considerable interest in exploration geophysics (Clark, 1983). The knowledge of the magnetic properties and thereby the mineral identification is also useful in magnetic fabric determinations for investigating the genesis and tectonic history of the deposit and for aiding the interpretation of the associated magnetic anomalies (Schwarz, 1975; Rochette, 1987).

Iron sulfides, particularly pyrrhotites, along with iron oxides, are the most important magnetic components in natural rocks, although the magnetic properties of the former presently are not well understood. During recent decades numerous rock and paleomagnetic investiga-

\footnotetext{
'Mottl, M.J., Davis, E.E., Fisher, A.T., and Slack, J.F. (Eds.), 1994. Proc. ODP, Sci. Results, 139: College Station, TX (Ocean Drilling Program).

${ }^{2}$ Institut für Allgemeine und Angewandte Geophysik, Ludwig-Maximilians-Universität, Theresienstrasse 41, 80333 München, Germany.
}

tions of iron oxides and iron-titanium oxides have been made, but there have been relatively few magnetic investigations of pyrrhotite and other iron sulfides. This is surprising because a great variety of different types of iron sulfides exist in nature, formed by various processes. Aside from their economic importance (sulfides occur in paragenesis with gold, platinum, nickel, copper, lead, and zinc ores), there is a rising scientific interest in these minerals. It appears that iron sulfides are more abundant in marine sediments than was previously assumed (e.g., Freeman, 1986). Many different types of iron sulfides are also found in metamorphic formations (Rochette, 1987).

Phase relations of the troilite-pyrrhotite-pyrite system $\left(\mathrm{FeS}-\mathrm{Fe}_{1-x} \mathrm{~S}-\right.$ $\mathrm{FeS}_{2}$ ) have been studied extensively, but still are not understood in detail. In the FeS-FeS 2 system, pyrrhotite is the major phase that is of significance to rock magnetism. The term pyrrhotite is used collectively for hexagonal and pseudohexagonal (monoclinic) iron sulfides of composition $\mathrm{Fe}_{1-\mathrm{x}} \mathrm{S}$, where the crystal structure is similar to that of Niccolite (NiAs). The parameter $\mathrm{x}$ accounts for vacancies at iron locations in the crystal structure, which cause an apparent increase in oxidation state from $\mathrm{Fe}^{2+}$ to $\mathrm{Fe}^{3+}$. The common range of $\mathrm{x}$ for naturally occurring samples is $0<x \leq 0.125$ (Kissin and Scott, 1982). Based on the magnetic properties the sulfides are classified into three series:

1. $0<x<0.07$ : metastable pyrrhotites (Fe-content $\geq 48$ atomic percent). [Atomic percent iron $=100 \times \mathrm{m} /(\mathrm{m}+\mathrm{n})$ for the compound $\mathrm{Fe}_{\mathrm{m}} \mathrm{S}_{\mathrm{n}}$ (e.g., Power and Fine, 1976).] These iron-rich pyrrhotites have nearly the same properties as troilite (FeS). At room temperature the crystal structure of their composition is hexagonal and their magnetic behavior is antiferromagnetic (Schwarz and Vaughan, 1972).

2. $0.07<x<0.11$ : intermediate iron/sulfur content (iron content between 48.0 and 47.3 atomic percent). In this range we find $\mathrm{Fe}_{11} \mathrm{~S}_{12}$, $\mathrm{Fe}_{10} \mathrm{~S}_{11}$, and $\mathrm{Fe}_{9} \mathrm{~S}_{10}$. Magnetic behavior at room temperature is antiferromagnetic but a small ferrimagnetic moment may exist (Nakazawa and Morimoto, 1971). According to Haraldsen (1941) the saturation magnetization increases suddenly at the $\gamma$-transition (antiferromagnetic-ferrimagnetic transition point). The $\gamma$-transition occurs between $\mathrm{T}_{\gamma}=210^{\circ} \mathrm{C}$ (Lotgering, 1956; Bennett and Graham, 1981) and $\mathrm{T}_{\gamma}=$ $220^{\circ} \mathrm{C}$ (Schwarz and Vaughan, 1972). Curie temperatures of the intermediate pyrrhotites depend on the composition and range between $\mathrm{T}_{\mathrm{c}}=200^{\circ} \mathrm{C}$ and $230^{\circ} \mathrm{C}$ for $0.07<\mathrm{x}<0.09\left(\mathrm{Fe}_{11} \mathrm{~S}_{12}\right)$ and between $\mathrm{T}_{\mathrm{c}}=$ $260^{\circ}$ and $270^{\circ} \mathrm{C}$ for $0.09<\mathrm{x}<0.11\left(\mathrm{Fe}_{10} \mathrm{~S}_{11}, \mathrm{Fe}_{9} \mathrm{~S}_{10}\right)$. 
Table 1. Summary of Curie temperatures and lattice parameters of samples from Holes $856 \mathrm{G}$ and $856 \mathrm{H}$.

\begin{tabular}{|c|c|c|c|c|c|c|c|c|c|c|c|c|c|c|}
\hline \multirow{2}{*}{$\begin{array}{l}\text { Core, section, } \\
\text { interval }(\mathrm{cm})\end{array}$} & \multirow[b]{2}{*}{ Piece } & \multirow{2}{*}{$\begin{array}{l}\text { Depth } \\
\text { (mbsf) }\end{array}$} & \multirow{2}{*}{$\begin{array}{c}\text { Lithologic } \\
\text { unit }\end{array}$} & \multicolumn{9}{|c|}{ Curie temperature and transition temperature $\left({ }^{\circ} \mathrm{C}\right)$} & \multirow{2}{*}{$\begin{array}{l}\text { Type of } \\
\text { curve }\end{array}$} & \multirow{2}{*}{$\begin{array}{c}\text { Cell edge of } \\
\text { magnetite } \\
\text { determined by } \\
\text { X-ray analyses }(\AA)\end{array}$} \\
\hline & & & & $\mathrm{T}_{\gamma}$ & $\mathrm{T}_{\mathrm{cl}}$ & $\mathrm{T}_{\mathrm{c} 2}$ & $T_{\mathrm{c} 3}$ & $\mathrm{~T}_{\mathrm{c4}}$ & $\mathrm{T}_{\mathrm{c5}}$ & $T_{c b}$ & $\mathrm{~T}_{\mathrm{c} 2}^{\prime}$ & $\mathrm{T}_{\mathrm{co}}^{\prime}$ & & \\
\hline \multicolumn{15}{|l|}{ 139-856G- } \\
\hline $3 R-1,100-102$ & 10 & 18.60 & 3 & & & & 448 & 499 & 516 & 579 & 228 & 546 & A & 8.412 \\
\hline $4 \mathrm{R}-1,60-62$ & 8 & 27.60 & 3 & & & & & & & 572 & 333 & 565 & A & 8.410 \\
\hline $4 \mathrm{R}-1,122-124$ & 17 & 28.22 & 3 & & & & & 484 & & 544 & 307 & 554 & A & 8.396 \\
\hline $4 \mathrm{R}-2,2-4$ & 1 & 28.46 & 1 & 209 & & & 414 & & & 570 & 309 & 555 & $\mathrm{~A} / \mathrm{B}$ & 8.413 \\
\hline $5 \mathrm{R}-1,34-36$ & 5 & 37.04 & 2 & 243 & & & 382 & & 528 & 582 & 300 & 549 & $\mathrm{~A} / \mathrm{B}$ & 8.396 \\
\hline $6 \mathrm{R}-2,80-82$ & 13 & 48.60 & 3 & & & & & 457 & 524 & 563 & 364 & 551 & A & 8.410 \\
\hline $6 R-4,5-7$ & 1 & 50.75 & 3 & & & 313 & 443 & & 524 & 576 & 313 & 558 & A & 8.423 \\
\hline $7 \mathrm{R}-1,23-25$ & 3 & 56.03 & 3 & & & & & $470 ?$ & & 583 & 462 & 576 & A & - \\
\hline $7 R-4,31-33$ & 4 & 60.41 & 5 & & & & & & & 580 & 477 & & A & 8.392 \\
\hline \multicolumn{15}{|l|}{$139-856 \mathrm{H}-$} \\
\hline $2 \mathrm{R}-1,32-34$ & 5 & 13.82 & 2 & 207 & & & & & & 573 & 328 & 548 & $\mathrm{~A} / \mathrm{B}$ & 8.422 \\
\hline $3 \mathrm{R}-1.87-89$ & $8 \mathrm{~B}$ & 22.97 & 4 & & & & & & & 555 & $305 / 336$ & 548 & A & 8.400 \\
\hline $3 R-2,121-123$ & $4 \mathrm{~A}$ & 24.47 & 4 & & & & & & & 559 & 309 & 546 & $\mathrm{~A}$ & 8.410 \\
\hline $3 R-3,61-63$ & 6 & 25.32 & 4 & & & & & & & 559 & 298 & 546 & A & 8.405 \\
\hline $4 \mathrm{R}-1,13-15$ & 3 & 26.73 & 4 & & & & & 488 & & 564 & 302 & 547 & A & 8.392 \\
\hline $4 \mathrm{R}-2,8-10$ & 2 & 28.18 & 4 & & & & & & 502 & 553 & $308 / 350$ & 542 & A & 8.402 \\
\hline $4 \mathrm{R}-3,2-4$ & 1 & 29.58 & 4 & 221 & & & & & & 551 & 309 & 553 & $\mathrm{~A} / \mathrm{B}$ & 8.390 \\
\hline $5 R-1,46-48$ & 8 & 32.86 & 2 & 185 & 273 & 321 & & & & & $279 / 321$ & 551 & C & - \\
\hline $6 \mathrm{R}-1,22-24$ & 4 & 37.62 & 2 & $229 / 255$ & & $326 / 371$ & & & & & 281 & 555 & D & - \\
\hline $7 \mathrm{R}-1,103-105$ & 16 & 44.13 & 2 & & & & & & & 549 & 294 & 537 & A & 8.385 \\
\hline $8 \mathrm{R}-1,121-123$ & 18 & 49.21 & 5 & & & & & & & 586 & 302 & 470 & $\mathrm{~A}$ & 8.406 \\
\hline $9 \mathrm{R}-1,18-19$ & 3 & 52.68 & 4 & & & & & 473 & & 575 & 306 & 552 & A & 8.410 \\
\hline $13 \mathrm{R}-1,37-39$ & 5 & 71.27 & 2 & & & & 414 & & & 593 & 324 & 558 & $\mathrm{~A}$ & 8.409 \\
\hline $14 \mathrm{R}-1,72-74$ & 12 & 76.42 & 1 & 214 & 244 & 306 & & & & 581 & $302 / 326$ & 533 & B & 8.397 \\
\hline $15 \mathrm{R}-1,109-111$ & 17 & 81.59 & 1 & 219 & 261 & 302 & & & & 569 & $309 / 381$ & 556 & B & - \\
\hline $16 \mathrm{R}-1,84-86$ & 17 & 86.04 & 1 & & & 323 & & & & 570 & 298 & 543 & D & - \\
\hline
\end{tabular}

Notes: $\mathrm{T}_{\gamma}=$ temperature of $\gamma$-transition of hexagonal pyrrhotite, $\mathrm{T}_{\mathrm{cl}}=$ Curie temperature from hexagonal pyrrhotite, $\mathrm{T}_{\mathrm{c} 2}=\mathrm{Curie-temperature} \mathrm{from} \mathrm{monoclinic} \mathrm{pyrrhotite,} \mathrm{T}_{\mathrm{c} 3}, \mathrm{~T}_{\mathrm{c} 4}, \mathrm{~T}_{\mathrm{c} 5}=$ converting temperatures from pyrite to a ferromagnetic mineral and the Curie temperature of this phase, $\mathrm{T}_{\mathrm{c} 6}=\mathrm{Curie}$ temperature of magnetite, $\mathrm{T}_{\mathrm{c} 2}^{\prime}, \mathrm{T}_{\mathrm{cb}}=\mathrm{Curie}$ temperature of the builded minerals estimated from cooling cycle. A, B, C, D are explained in text. $-=$ no magnetite detected.

3. $0.11<x<0.125$ : high sulfur content, low iron content $(47.0-$ 46.5 atomic percent). The sulfides with high sulfur content show a spontaneous magnetization. The most interesting mineral in this group is the monoclinic $\mathrm{Fe}_{7} \mathrm{~S}_{8}$. The monoclinic pyrrhotite is a stable phase below about $230^{\circ} \mathrm{C}$. Between $230^{\circ} \mathrm{C}$ and about $300^{\circ}-350^{\circ} \mathrm{C}$ it is metastable and tends to convert slowly to pyrite and hexagonal pyrrhotite (Ward, 1970). Graham et al. (1987) showed that the environment (e.g., fugacity of $\mathrm{O}_{2}$ ) is an important factor in mineral change. The Curie temperature is between $300^{\circ} \mathrm{C}$ (Lotgering, 1956) and $350^{\circ} \mathrm{C}$ (Brodskaya et al., 1976) for $\mathrm{Fe}_{7} \mathrm{~S}_{8}$ and decreases with decreasing sulfur content. Saturation magnetization is reported to be $20 \mathrm{Am}^{2} / \mathrm{kg}$ (Schwarz and Vaughan, 1972; Halgedahl and Fuller, 1981). At room temperature the (001) plane is that of easy magnetization, and the [001] direction is the hard direction of magnetization. According to Bin and Pauthenet (1963), crystal anisotropy is high. Soffel $(1977,1981)$ investigated the domain structure of natural fine-grained pyrrhotite in a diabase using the Bitter pattern technique (Bitter, 1931). Extrapolation of the empirical relationship between grain size and the number of domains yields a value of $1.6 \mu \mathrm{m}$ for the critical single-domain to two-domain transition. Clark (1984) calculated a value of $2.9 \mu \mathrm{m}$.

\section{METHODS}

Holes $856 \mathrm{G}$ and $856 \mathrm{H}$ were drilled on the top of the sulfide ridge in the presumed center of the hydrothermal sulfide deposit. Nine samples from Hole $856 \mathrm{G}$ and 16 samples from Hole $856 \mathrm{H}$ from different lithologic subunits were investigated. Sulfide samples from these holes were classified on the basis of macroscopic descriptive attributes of the core. Based on the content of principal minerals, six types were defined in Davis, Mottl, Fisher, et al. (1992). These are as follows:

Type 1: Homogenous, massive, fine-grained pyrrhotite

Type 2: Homogenous, massive, fine-grained pyrite-pyrrhotite

Type 3: Homogenous, medium- to coarse-grained pyrite-pyrrhotite

Type 4: Heterogeneous and veined coarse-grained pyrite-pyrrhotite

Type 5: Massive colloform and vuggy pyrite

Type 6: Sediment with sulfide veining
The classification for the investigated samples is summarized in Table 1.

Samples for rock magnetic investigations were cut from 1-in. drill cores, from 1-in. cubes, or from amorphous rock samples. Natural remanent magnetization (NRM) and acquisition curves of isothermal remanent magnetization (IRM) were determined with a Molspin spinner magnetometer. The IRM was produced with a coil for fields up to $140 \mathrm{mT}$ and with an electromagnet for fields up to $1500 \mathrm{mT}$. Alternating field (AF) demagnetization of the natural remanent magnetization and of the IRM was done statically in three directions in a $2 \mathrm{G}$ demagnetizer. Initial susceptibility was measured with a Jelinek KLY1 susceptibility bridge (Geofysika, Brno, Czech Rep.). Curie temperatures were determined with a horizontal Curie balance by heating small rock fragments, which were cut from the cores and cubes or amorphous samples. Most of the time saturation magnetization as a function of temperature, $\mathrm{J}_{\mathrm{s}}(\mathrm{T})$, was measured during a heating and cooling cycle in air. Some of the samples were sealed and evacuated in glass tubes. The applied magnetic field of the Curie balance was set to 0.35 $\mathrm{T}$ and the heating rate amounted to $50^{\circ} \mathrm{C} / \mathrm{min}$. A thermal lag between the measured temperature and the temperature of the samples was not observed. To determine the Curie temperature the intersection of two tangents to the $\mathrm{J}_{\mathrm{s}}(\mathrm{T})$ curves above and below $\mathrm{T}_{\mathrm{c}}$ was used (Grommé et al., 1969). The estimated error in the Curie temperature determinations is $<10^{\circ} \mathrm{C}$. Transition temperatures for pyrrhotites were determined with the same method. Hysteresis properties determined from hysteresis loop measurements were used to estimate the magnetic mineral content, stability, the domain state of the minerals, and the thus indirectly the grain size of the samples with predominant one magnetic phase. Hysteresis loops were measured with a vibrating sample magnetometer (VSM).

The samples were further characterized with X-ray diffraction. For that purpose, the magnetic particles were separated with a hand magnet from a suspension of the ground sample in water. A powder spectrometer was used with $\mathrm{CuK}_{\alpha}$ radiation and $\mathrm{Si}$ as an internal calibration standard. The cell edge was calculated for the cubic Feoxides from at least three well-defined peaks. The analysis of pyrrhotite by X-ray diffraction is based on the (102)-spacing (Arnold, 
1962; Desborough and Carpenter, 1965; Scott, 1974). This method is acceptable as long as the phases are homogenous and there are not more than two components in the solid solution (Scott, 1974). The interpretation of the powder diffraction pattern depends on the distinction of the hexagonal peak and both monoclinic peaks.

Polished sections were prepared from all 25 investigated samples and were examined by ore microscopy using a reflected light microscope to determine the mineralogy and textural relationships of the sulfides. Monoclinic and hexagonal pyrrhotites were distinguished by applying a thin layer of ferrofluid, which is attracted by the magnetic grains in the samples (Bitter, 1931). The ferrofluid method reveals inhomogeneities in magnetic particles such as those caused by the exsolution of lamellae or shows domain structures in magnetic pyrrhotite grains.

\section{RESULTS AND DISCUSSION}

\section{Remanence Properties and Magnetic Susceptibility}

In order to obtain information on the types of magnetic minerals present in the samples from Holes $856 \mathrm{G}$ and $856 \mathrm{H}$, IRM acquisition and $\mathrm{AF}$ demagnetization data were collected for all samples. IRM acquisition curves (Fig. 1) show the different behavior of saturation for samples containing mainly magnetite and samples in which the magnetization is carried by pyrrhotite. Sample 139-856G-5R-1, 34 $36 \mathrm{~cm}$, consists of magnetite as the only magnetic phase. This sample saturates in much weaker fields (at about $100 \mathrm{mT}$ ) than the samples containing pyrrhotite.

The magnetic susceptibility, $\chi$, of natural materials in weak magnetic fields depends on the kind, abundance, and grain size of ferromagnetic minerals in a complicated manner. Nevertheless there seems to be a correlation between magnetic susceptibility and the concentration of ferro(i)magnetic minerals in rocks (Petersen and Bleil, 1982). Sulfide samples from Holes $856 \mathrm{G}$ and $856 \mathrm{H}$ show values between 1 $\times 10^{-3}$ and 0.5 (SI units). Thompson and Oldfield (1986) presented the dependence of saturation remanence and susceptibility in a bilogarithmic diagram. Calibration of the parameters was based on 1000 naturally occurring samples. Results from the samples investigated for the present study containing mainly magnetite are plotted in this diagram (Fig. 2). The magnetic grain size of the magnetites is estimated to vary between about 1 and $100 \mu \mathrm{m}$.

\section{Hysteresis Properties}

Hysteresis parameters determined from rock samples from Holes $856 \mathrm{G}$ and $856 \mathrm{H}$ are presented in Table 2 and are plotted vs. depth in Figure 3. Samples from Hole $856 \mathrm{G}$ and the mainly magnetitecontrolled samples from Hole $856 \mathrm{H}$ were saturated at about $500 \mathrm{mT}$. Samples containing monoclinic pyrrhotite needed higher fields to reach saturation; an acquisition field of $1000 \mathrm{mT}$ was not sufficient. A hysteresis loop for Sample 139-856H-6R-1, 22-24 cm, containing mainly monoclinic pyrrhotite, is shown in Figure 4 . The rectangle shape is typical for monoclinic pyrrhotites and has been observed previously (e.g., Menyeh and O'Reilly, 1991). Values of saturation magnetization, $\mathrm{J}_{s}$, for Hole $856 \mathrm{G}$ and $856 \mathrm{H}$ samples vary between 90 and $20000 \mathrm{~mA} \times \mathrm{m}^{2} / \mathrm{kg}$. Most samples have values at about 10000 $\mathrm{mA} \times \mathrm{m}^{2} / \mathrm{kg}$, except for two samples from Holes $856 \mathrm{G}$ and three samples from Hole $856 \mathrm{H}$, which have much lower values (Table 2). Saturation remanence varies between about 9 and $4000 \mathrm{~mA} \times \mathrm{m}^{2} / \mathrm{kg}$. The ratio of saturation remanence to saturation magnetization, $\mathrm{J}_{\mathrm{rs}} / \mathrm{J}_{\mathrm{s}}$, is used as an estimate of the magnetic domain structure or magnetic grain size (Day et al., 1977). Theoretical calculations show that ideally $\mathrm{J}_{\mathrm{rs}} / \mathrm{J}_{\mathrm{s}}$ is 0.5 for single-domain magnetites. Magnetization ratios less than 0.05 are characteristic for multidomain magnetite grains. $\mathrm{J}_{\mathrm{rs}} / \mathrm{J}_{\mathrm{s}}$ values in the present study vary between 0.05 and 0.15 in samples in which magnetite is the only magnetic mineral. Samples that contain predominantly pyrrhotites show $\mathrm{J}_{\mathrm{rs}} / \mathrm{J}_{\mathrm{s}}$ ratios between 0.25 and 0.47 . This is in good agreement with the results of Rochette et al.

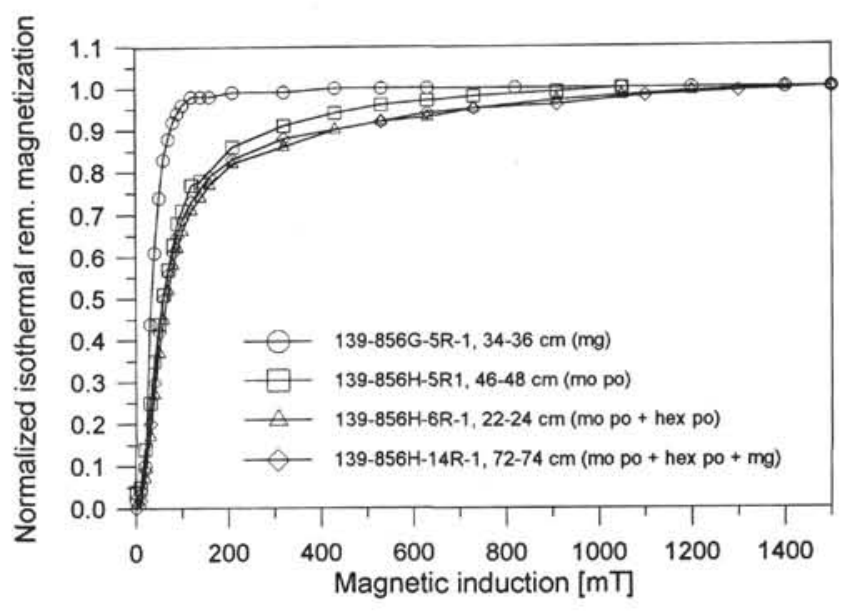

Figure 1. Acquisition curves of the isothermal remanent magnetization normalized to their remanence value at the maximum available field of $1.5 \mathrm{~T} . \mathrm{Mg}=$ magnetite mo po = monoclinic pyrrhotite hex $\mathrm{po}=$ hexagonal pyrrhotite .

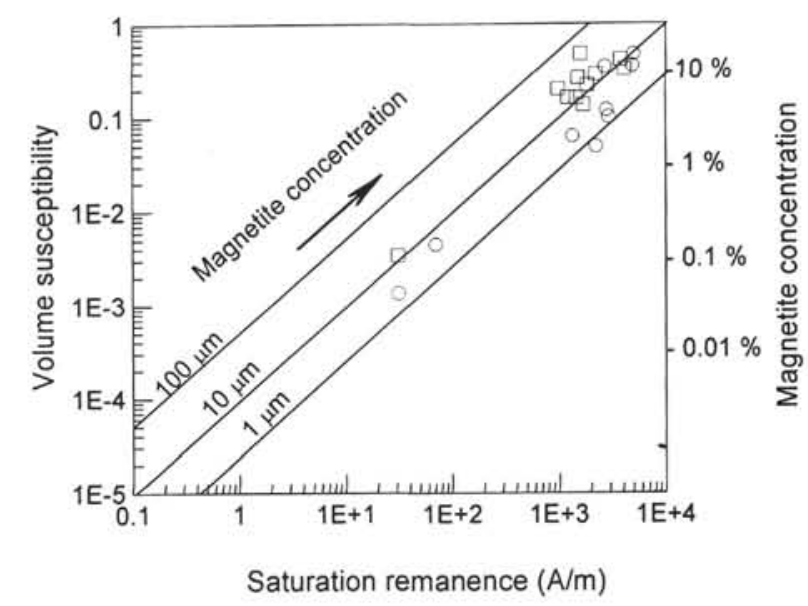

Figure 2. Bilogarithmic plot of saturation remanence vs. susceptibility for magnetite-bearing samples from Hole $856 \mathrm{G}$ (circles) and Hole $856 \mathrm{H}$ (squares) (after Thompson and Oldfield, 1986). The concentration and grain size values apply to pure magnetite.

(1989), who showed that the ratio $\mathrm{J}_{\mathrm{rs}} / \mathrm{J}_{\mathrm{s}}$ is greater than 0.2 for pyrrhotite and less than 0.2 for multidomain magnetite. Menyeh and O'Reilly (1991) measured $J_{\mathrm{rs}} / \mathrm{J}_{\mathrm{s}}$ values between 0.484 and 0.380 on synthetic pyrrhotite for grain sizes between 0.8 and $29 \mu \mathrm{m}$.

Coercive force, $\mathrm{B}_{\mathrm{c}}$, and remanence coercive force, $\mathrm{B}_{\mathrm{cr}}$, are used to estimate the stability of magnetization. These parameters are generally correlated with $\mathrm{J}_{\mathrm{rs}} / \mathrm{J}_{\mathrm{s}}$ and magnetic grain size. Higher coercivity is associated with smaller magnetic grains (higher $\mathrm{J}_{\mathrm{rs}} / \mathrm{J}_{\mathrm{s}}$ ). Investigated samples from Holes $856 \mathrm{G}$ and $856 \mathrm{H}$ show a wide range of coercive force values between 2.5 and $40 \mathrm{mT}$. The samples containing primary magnetite have generally lower coercive forces $\left(B_{c}\right.$ between 2.5 and $12.5 \mathrm{mT})$ than the samples containing mainly pyrrhotites $\left(B_{c}\right.$ between 24 and $40 \mathrm{mT}$ ). The remanence coercive force ranges between 9 and $27 \mathrm{mT}$ for magnetite-dominant samples and between 39 and $54 \mathrm{mT}$ for pyrrhotite-dominant samples. $\mathrm{B}_{\mathrm{cr}} / \mathrm{B}_{\mathrm{c}}$ is another measure of stability. It increases with increasing grain size. $\mathrm{J}_{\mathrm{rg}} / \mathrm{J}_{\mathrm{s}}$ and $\mathrm{B}_{\mathrm{cr}} / \mathrm{B}_{\mathrm{c}}$ for the magnetite-dominant samples from Holes $856 \mathrm{G}$ and $856 \mathrm{H}$ are plotted together in Figure 5. Based on the results, the estimated magnetic grain size of the magnetites is between pseudo-single-domain (PSD) and multidomain (MD). The low $\mathrm{B}_{\mathrm{cr}} / \mathrm{B}_{\mathrm{c}}$ ratio, which is approximately independent of grain size, is typical for pyrrhotite (Dekkers, 1988). 


\section{U. KÖRNER}

Table 2. Summary of hysteresis parameters and susceptibility values of samples from Holes 856G and 856H.

\begin{tabular}{|c|c|c|c|c|c|c|c|c|c|c|c|}
\hline $\begin{array}{l}\text { Core, section, } \\
\text { interval }(\mathrm{cm})\end{array}$ & Piece & $\begin{array}{l}\text { Depth } \\
\text { (mbsf) }\end{array}$ & $\begin{array}{c}\text { Lithologic } \\
\text { unit }\end{array}$ & $\begin{array}{c}\text { Volume } \\
\text { susceptibility } \\
\left(10^{-3} \mathrm{SI}\right)\end{array}$ & $\left(\mathrm{mA} \cdot \mathrm{J}^{2} / \mathrm{kg}\right)$ & $\left(\mathrm{mA} \cdot \mathrm{m}^{2} / \mathrm{kg}\right)$ & $\mathrm{J}_{\mathrm{rs}} / \mathrm{J}_{\mathrm{s}}$ & $\begin{array}{c}\mathrm{B}_{c} \\
(\mathrm{mT})\end{array}$ & $\begin{array}{l}\mathrm{B}_{\mathrm{cr}} \\
(\mathrm{mT})\end{array}$ & $\mathrm{B}_{\mathrm{cr}} / \mathrm{B}_{\mathrm{c}}$ & $\begin{array}{c}\text { Dominant } \\
\text { magnetic } \\
\text { species }\end{array}$ \\
\hline \multicolumn{12}{|l|}{$139-856 \mathrm{G}-$} \\
\hline $3 \mathrm{R}-1,100-102$ & 10 & 18.60 & 3 & 119.5 & 844 & 5690 & 0.148 & 10.5 & 21 & 2.00 & mag \\
\hline $4 \mathrm{R}-1,60-62$ & 8 & 27.60 & 3 & 470 & 1500 & 19540 & 0.077 & 7 & 13.5 & 1.93 & mag \\
\hline $4 \mathrm{R}-1,122-124$ & 17 & 28.22 & 3 & 351 & 1360 & 15010 & 0.091 & 9 & 19 & 2.11 & mag \\
\hline $4 R-2,2-4$ & 1 & 28.46 & 1 & 48 & 725 & 6380 & 0.114 & 8.5 & 23.5 & 2.76 & mag + hex po \\
\hline $5 \mathrm{R}-1,34-36$ & 5 & 37.04 & 2 & 100 & 956 & 6060 & 0.158 & 12.5 & 25 & 2.00 & mag + hex po \\
\hline $6 \mathrm{R}-2,80-82$ & 13 & 48.60 & 3 & 345 & 801 & 16140 & 0.050 & 4 & 14 & 3.50 & mag \\
\hline $6 \mathrm{R}-4,5-7$ & I & 50.75 & 3 & 62.3 & 436 & 5180 & 0.084 & 6.5 & 26.5 & 4.08 & mag \\
\hline $7 \mathrm{R}-1,23-25$ & 3 & 56.03 & 3 & 4.5 & 32.1 & 243 & 0.132 & 9 & 27 & 3.00 & mag \\
\hline $7 \mathrm{R}-4,31-33$ & 4 & 60.41 & 5 & 1.35 & 9.4 & 92 & 0.102 & 6.5 & 22 & 3.38 & mag \\
\hline \multicolumn{12}{|l|}{$139.856 \mathrm{H}-$} \\
\hline $2 \mathrm{R}-1,32-34$ & 5 & 13.82 & 2 & 199 & 394 & 5240 & 0.075 & 3.5 & 13 & 3.71 & mag + hex po \\
\hline $3 \mathrm{R}-1,87-89$ & $8 \mathrm{~B}$ & 22.97 & 4 & 219 & 724 & 9870 & 0.073 & 5 & 13 & 2.60 & mag + few hex po \\
\hline $3 R-2,121-123$ & $4 \mathrm{~A}$ & 24.47 & 4 & 409 & 1124 & 14890 & 0.075 & 6.5 & 17 & 2.62 & $\mathrm{mag}$ \\
\hline $3 R-3,61-63$ & 6 & 25.32 & 4 & 326 & 1325 & 16710 & 0.079 & 6.5 & 16 & 2.46 & mag \\
\hline $4 \mathrm{R}-1,13-15$ & 3 & 26.73 & 4 & 160 & 541 & 8520 & 0.064 & 5 & 15 & 3.00 & mag \\
\hline $4 \mathrm{R}-2,8-9$ & 2 & 28.18 & 4 & 288 & 695 & 1170 & 0.063 & 4.5 & 14 & 3.11 & mag \\
\hline $5 \mathrm{R}-1,46-48$ & 8 & 32.86 & 2 & 32.2 & 2290 & 8330 & 0.275 & 29 & 43 & 1,48 & mono po + few hex po \\
\hline $6 \mathrm{R}-1,22-24$ & 4 & 37.62 & 2 & 2.64 & 296 & 636 & 0.466 & 40 & 54 & 1.35 & hex po + few mono po \\
\hline $7 R-1,103-105$ & 16 & 44.13 & 2 & 265 & 463 & 7820 & 0.059 & 4.5 & 16 & 3.56 & mag \\
\hline $8 \mathrm{R}-1,121-123$ & 18 & 49.21 & 5 & 3.41 & 10.9 & 204 & 0.053 & 2.5 & 9 & 3.60 & mag \\
\hline $9 \mathrm{R}-1,18-19$ & 3 & 52.68 & 4 & 472 & 708 & 17280 & 0.041 & 3 & 15.5 & 5.17 & $\mathrm{mag}$ \\
\hline $13 R-1,37-39$ & 5 & 71.27 & 2 & 162 & 439 & 7710 & 0.057 & 5 & 16.5 & 3.30 & mag \\
\hline $14 \mathrm{R}-1,72-74$ & 12 & 76.42 & 1 & 47.3 & 1300 & 5060 & 0.257 & 24 & 45 & 1.88 & hex po + mono po + mag \\
\hline $15 R-1,109-111$ & 17 & 81.59 & 1 & 48.3 & 870 & 2310 & 0.377 & 31 & 41 & 1.32 & hex po + mono po \\
\hline $16 \mathrm{R}-1,84-86$ & 17 & 86.04 & i & 65.6 & 3600 & 10160 & 0.354 & 35 & 39 & 1.11 & mono po + mag \\
\hline
\end{tabular}

Notes: $\mathrm{J}_{\mathrm{rs}}=$ saturation remanence; $\mathrm{J}_{\mathrm{s}}=$ saturation magnetization; $\mathrm{B}_{\mathrm{c}}=$ coercive force; $\mathrm{B}_{\mathrm{ct}}=$ remanence coercive force; mag $=$ magnetite; mono po=monoclinic pyrrhotite; hex po $=$ hexagonal pyrrhotite.

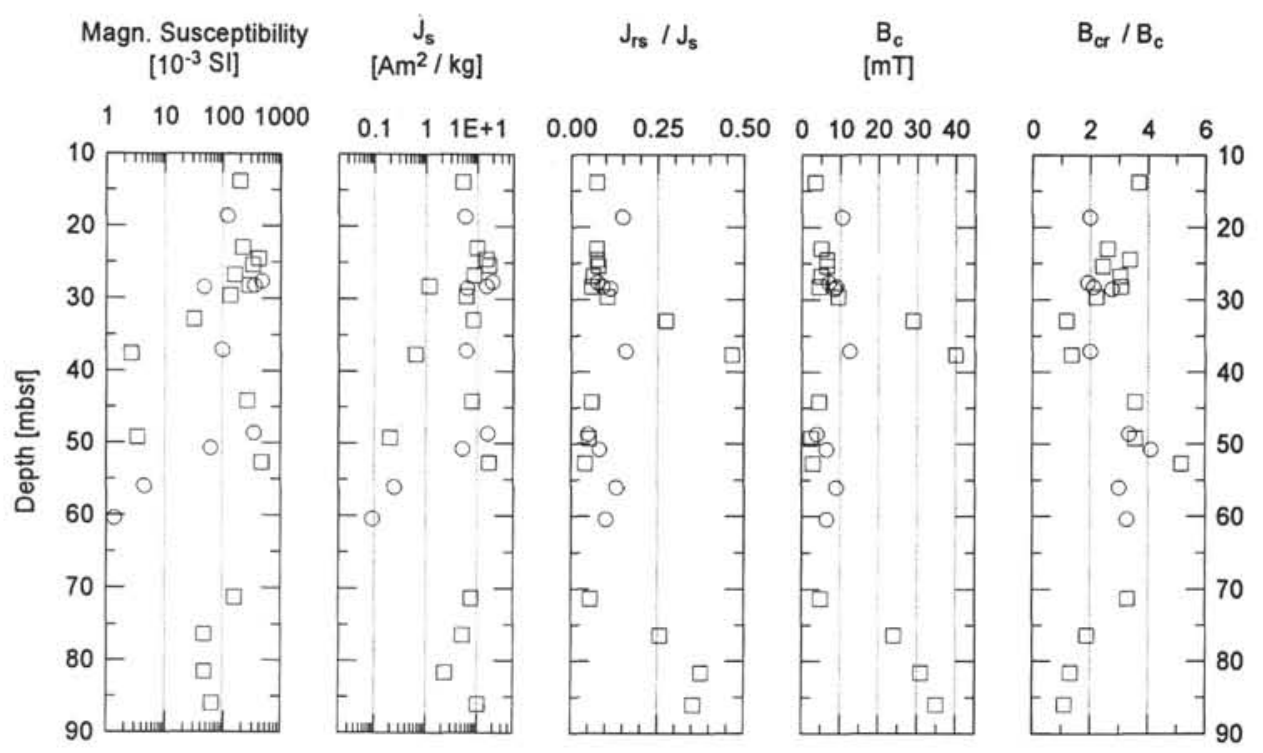

Figure 3. Depth variation of hysteresis properties of sulfides from Holes $856 \mathrm{G}$ (circles) and $856 \mathrm{H}$ (squares).

The grain size of pyrrhotite can be estimated from $\mathrm{B}_{\mathrm{c}}$ and $\mathrm{B}_{\mathrm{cr}}$ values. $\mathrm{A}$ comparison with the results of samples investigated by Clark (1984), Dekkers (1988), and Menyeh and O'Reilly (1991) points to magnetic grain sizes of pyrrhotites between 10 and $50 \mu \mathrm{m}$.

\section{Thermomagnetic Identification of the Magnetic Minerals}

The Curie temperature of iron sulfides depends heavily on the $\mathrm{Fe} / \mathrm{S}$ ratio. This ratio can be determined from the thermomagnetic curve, which represents the change in magnetization with temperature (Schwarz, 1975). Investigations of samples collected during Leg 139 show that magnetite (for samples from Holes $856 \mathrm{G}$ and $856 \mathrm{H}$ ) and pyrrhotite (for samples from Hole $856 \mathrm{H}$, monoclinic as well as hexagonal) are magnetically dominant.

Samples from Hole $856 \mathrm{G}$ show Curie temperatures mainly between $544^{\circ}$ and $583^{\circ} \mathrm{C}$ with an average value of $572^{\circ} \pm 12^{\circ} \mathrm{C}$, suggesting the presence of magnetite. Titanomagnetite is unlikely to be present because no titanium was detected in sulfide samples from Holes $856 \mathrm{G}$ and $856 \mathrm{H}$. In addition, observed transition temperatures between $443^{\circ}$ and $528^{\circ} \mathrm{C}$ (see Table 1) seem to be transition points where pyrite converts to a ferro(i)magnetic phase, which may be magnetite. Two samples from Hole 856G (-4R-2, 2-4 cm and $-5 R-1$, $34-36 \mathrm{~cm}$ ) show a small increase in the magnetization at temperatures between $209^{\circ}$ and $243^{\circ} \mathrm{C}$. This might be an indication of small 


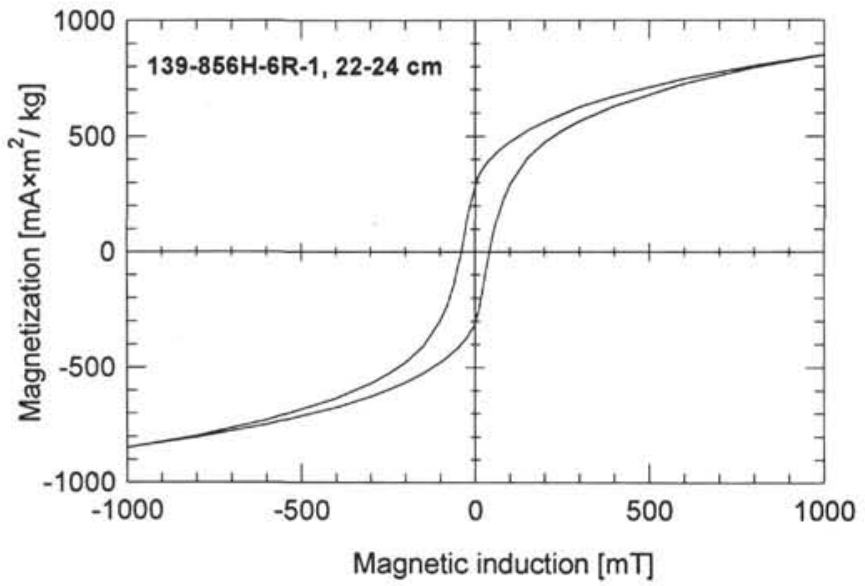

Figure 4. Hysteresis loop at room temperature for a whole-rock sample. The maximum available field of $1000 \mathrm{mT}$ fails to saturate the material. Magnetomineralogical methods show that this sample contains mainly monoclinic pyrrhotite $\left(\mathrm{Fe}_{7} \mathrm{~S}_{8}\right)$.

amounts of hexagonal pyrrhotite in these samples, although typical Curie temperatures of hexagonal pyrrhotites were not observed. Apart from the magnetite Curie point, some samples from Hole $856 \mathrm{H}$ (e.g., $-4 \mathrm{R}-3,2-4 \mathrm{~cm}$; -6R-1, 22-24 cm; -14R-1, 72-74 cm, and -15R-1, $109-111 \mathrm{~cm}$ ) show transition temperatures for hexagonal pyrrhotite (about $220^{\circ} \mathrm{C}$ ), at which magnetization increases and Curie temperatures between $244^{\circ}$ and $273^{\circ} \mathrm{C}$ are present. In addition, typical Curie points for monoclinic pyrrhotites $\left(\mathrm{Fe}_{7} \mathrm{~S}_{8}\right)$ are observed between $302^{\circ}$ and $327^{\circ} \mathrm{C}$. Four characteristic curves are shown in Figure 6 . The type of the thermomagnetic curve for Sample 139-856H-7R-1, 103-105 cm (marked as curve type A in Table 1) was found to be common in the samples from Hole $856 \mathrm{G}$ and some samples from Hole $856 \mathrm{H}$, indicating that magnetite is the only magnetic phase. The curve for Sample 139-856H-15R-1, 109-111 cm, (marked as curve type B in Table 1) indicates a mixture of monoclinic and hexagonal pyrrhotite plus small amounts of magnetite. During heating the $\gamma$-transition of $\mathrm{Fe}_{9} \mathrm{~S}_{10}$ from antiferro- to ferrimagnetism was observed at $219^{\circ} \mathrm{C}$, and the Curie temperatures of $\mathrm{Fe}_{9} \mathrm{~S}_{10}\left(\mathrm{~T}_{\mathrm{cl}}=261^{\circ} \mathrm{C}\right)$ and $\mathrm{Fe}_{7} \mathrm{~S}_{8}\left(\mathrm{~T}_{\mathrm{c} 2}=302^{\circ} \mathrm{C}\right)$ were determined. Rapid cooling quenches the high-temperature ferrimagnetic structure of $\mathrm{Fe}_{9} \mathrm{~S}_{10}$ so that the $\gamma$-transition is skipped in the cooling cycle. The increase in magnetization indicates that probably pyrite was altered into magnetite after heating to $600^{\circ} \mathrm{C}$. The thermomagnetic curve of Sample 139-856H-5R-1, 46-48 cm, (curve type C in Table 1) shows monoclinic and hexagonal pyrrhotite similar as for type B, although no magnetite was observed before heating up to $660^{\circ} \mathrm{C}$. Sample $139-856 \mathrm{H}-16 \mathrm{R}-1,84-86 \mathrm{~cm}$, shows a thermomagnetic curve for monoclinic pyrrhotite plus small amounts of magnetite (curve type D in Table 1). The Curie temperature of the magnetite phase from Hole $856 \mathrm{H}$ varies between $551^{\circ} \mathrm{C}$ and $593^{\circ} \mathrm{C}$ with an average value of $567^{\circ}$ $\pm 14^{\circ} \mathrm{C}$ (see Table 1). Cation impurities may explain Curie temperatures that are lower than those typical of magnetite. Graham et al. (1987) observed thermomagnetic curves of magnetite, in which the Curie temperature had been lowered (by up to $140^{\circ} \mathrm{C}$ depending on cooling rates), and suggested that this observation resulted from oxygen solubility in magnetite and pyrrhotite. During cooling every sample from Hole $856 \mathrm{H}$ showed at least two Curie temperatures and an increase in magnetization. This increase appears to be due to an increase in magnetite content formed by the oxidation of pyrite during heating in air. The observed Curie temperatures are from the magnetite phase $\left(\mathrm{T}_{\mathrm{c} 6}^{\prime}\right.$ in Table 1) and probably from pyrrhotite $\left(\mathrm{T}_{\mathrm{c} 2}^{\prime}\right.$ in Table 1). The mean value calculated for all $\mathrm{T}_{\mathrm{c} 2}^{\prime}$ is about $325^{\circ} \pm 50^{\circ} \mathrm{C}$. Samples that were evacuated in glass tubes show near-perfect reversibility of the thermomagnetic curves. The Curie temperatures visible on the

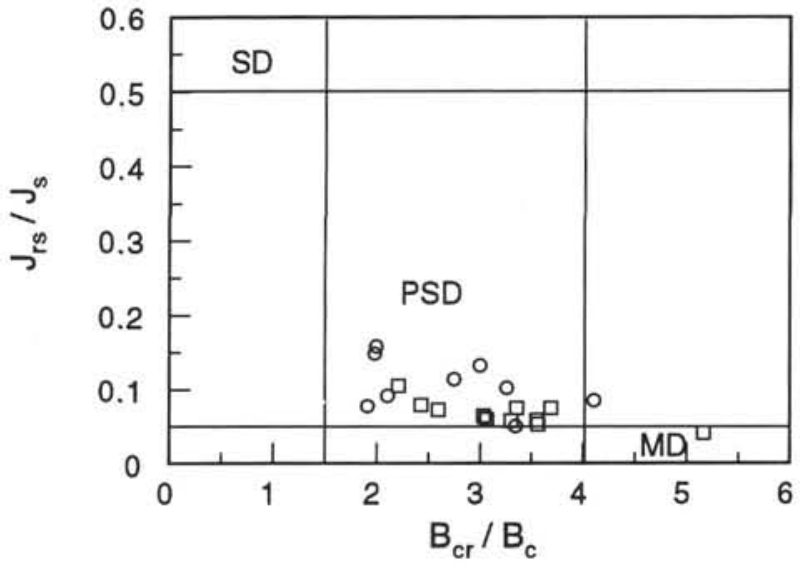

Figure 5. Plot of $\mathrm{J}_{\mathrm{rs}} / \mathrm{J}_{\mathrm{s}}$ vs. $\mathrm{B}_{\mathrm{cr}} / \mathrm{B}_{\mathrm{c}}$ for samples from Site 856 containing mainly magnetite as magnetic mineral. SD, PSD, and MD denote the range of singledomain, pseudo-single domain, and multidomain grains proposed by Day et al. (1977).

heating curve of the sealed samples do not differ from those of the unsealed samples.

\section{X-ray Diffraction}

Magnetite lattice constants for Hole $856 \mathrm{G}$ and $856 \mathrm{H}$ samples were calculated to be between 8.392 and $8.423 \AA$, with a mean of $8.404 \pm$ $0.010 \AA$ (Table 1). Compared with the established lattice constant of magnetite $(8.396 \AA)$ the determined values are somewhat high, but within the estimated range of error. The lattice constant for these samples may be stretched by cation impurities. Sulfides were identified by comparing d-spacings with the standard ASTM values.

\section{Ore Microscopy}

Pyrite, pyrrhotite, and magnetite were identified as major opaque minerals in the massive sulfides by reflected light microscopy. Chalcopyrite, sphalerite, hematite, and traces of marcasite were also observed in some samples. For magnetic investigations magnetite and pyrrhotite are the most significant minerals in massive sulfides. Magnetite was found in nearly every sample from Holes $856 \mathrm{G}$ and $856 \mathrm{H}$ (except Sample 856H-5R-1, 46-48 cm and 856H-6R-1, 22-24 cm) and is present in amounts up to 12 volume percent (vol\%). The observed grain sizes range between 1 and $500 \mu \mathrm{m}$. Idiomorphic crystals of magnetite with grain sizes up to $200 \mu \mathrm{m}$ are present in Sample $139-856 \mathrm{H}-3 \mathrm{R}-3,61-63 \mathrm{~cm}$. Analyzed samples from Hole $856 \mathrm{G}$ have pyrrhotite contents up to $2 \mathrm{vol} \%$. Samples from Hole $856 \mathrm{H}$ contain up to $75 \mathrm{vol} \%$ pyrrhotite with grain sizes of the crystallites up to $50 \mu \mathrm{m}$. Some pyrrhotites have grain sizes up to $1000 \mu \mathrm{m}$ subdivided in crystallites between 20 and $50 \mu \mathrm{m}$. Magnetic and nonmagnetic minerals were distinguished with the Bitter pattern technique (Bitter, 1931).

As described previously monoclinic pyrrhotite is ferrimagnetic at room temperature and because of its uniaxial symmetry the multidomain grains have a rather simple domain structure (Soffel, 1977, 1981). An example of monoclinic polycrystalline pyrrhotites covered with ferrofluid and photographed with crossed nicols is shown in Figure 7. The subdivision in crystallites with grain sizes of about 10-50 $\mu \mathrm{m}$ is visible.

Figure 8 also shows a monoclinic pyrrhotite covered with ferrofluid. The parallel domain structure is the result of the crystal symmetry and the large magnetocrystalline anisotropy. The apparent bend of the easy axis is caused by the subdivision in different crystallites building the big pyrrhotite crystal. 

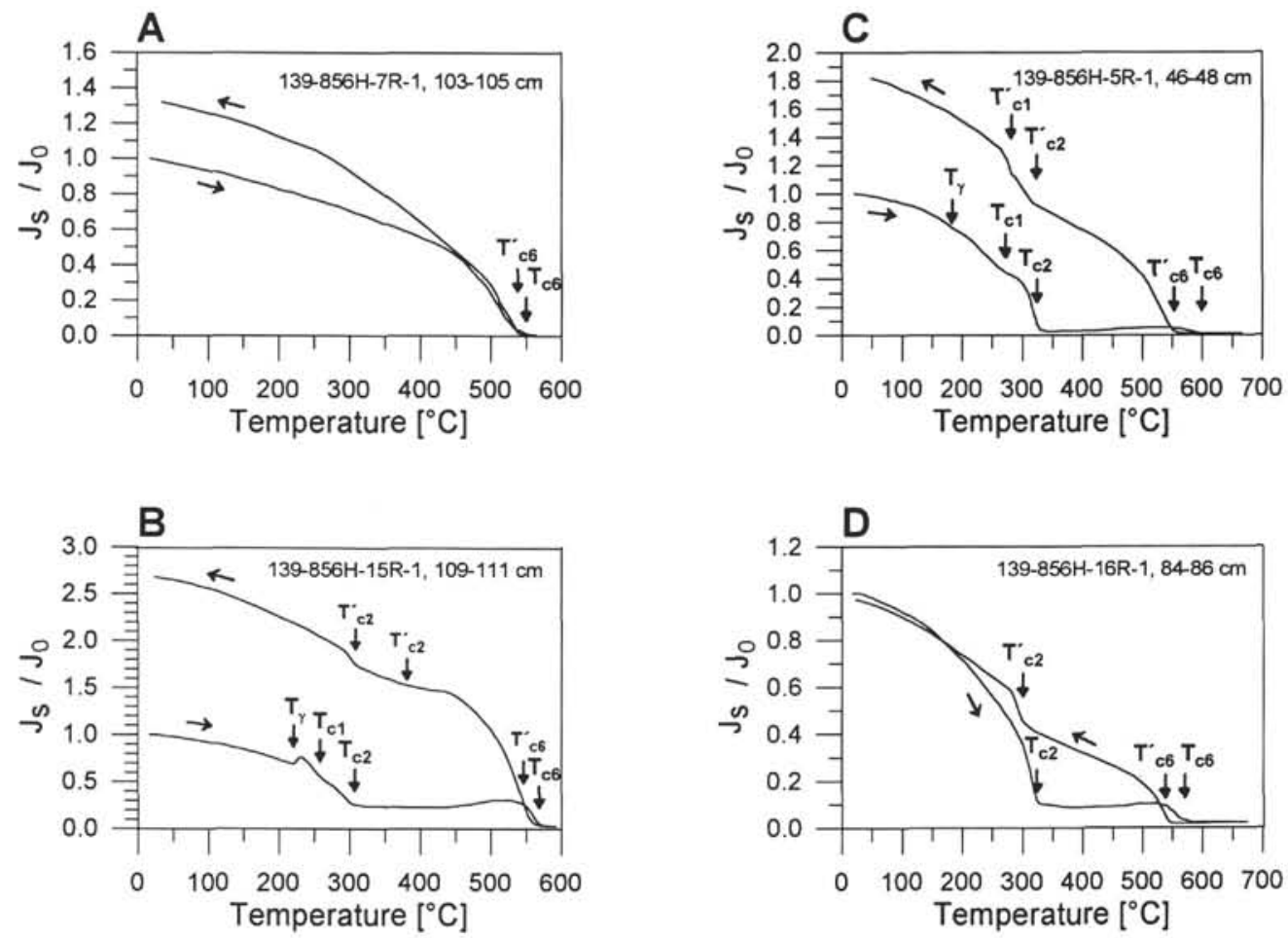

Figure 6. Thermomagnetic curves of magnetization vs. temperature for pyrrhotite-magnetite mixtures from Hole $856 \mathrm{H}$. Samples were measured in air in an applied magnetic field of $0.35 \mathrm{~T}$. The heating rate was set to $50^{\circ} \mathrm{C} / \mathrm{min}$. $\mathrm{T}_{\gamma}$ is the antiferro/ferrimagnetism transition of $\mathrm{Fe}_{9} \mathrm{~S}_{10} \cdot \mathrm{T}_{\mathrm{cl}}$ and $\mathrm{T}_{\mathrm{c} 2}$ are the Curie temperatures of $\mathrm{Fe}_{9} \mathrm{~S}_{10}$ and $\mathrm{Fe}_{7} \mathrm{~S}_{8} . \mathrm{T}_{\mathrm{c} 6}$ is the Curie temperature of magnetite. $\mathrm{T}_{\mathrm{c} 2}^{\prime}$ and $\mathrm{T}_{\mathrm{c} 6}^{\prime}$ are the Curie temperatures during cooling. A. Mainly magnetite as magnetic phase. B. A mixture of monoclinic pyrrhotite, hexagonal pyrrhotite, and magnetite. C. Pyrrhotites (monoclinic and hexagonal). D. Monoclinic pyrrhotite and minor magnetite.

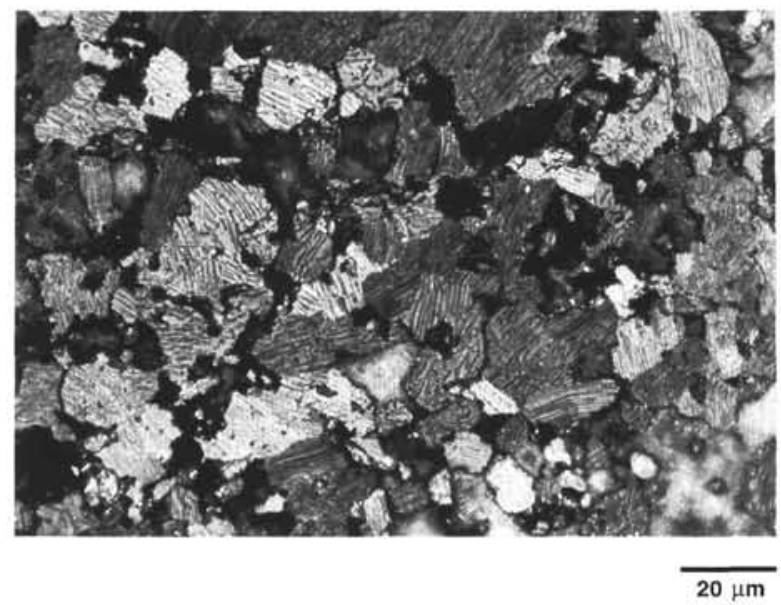

Figure 7. Photomicrograph of polished section from Sample 139-856H-5R-1, $46-48 \mathrm{~cm}$, covered with magnetic colloid and viewed in reflected light under crossed nicols. The domain structure of the monoclinic pyrrhotite particles is visible. The domain walls appear as dark lines.

Several samples show pyrrhotite grains that are nonmagnetic in the center (hexagonal pyrrhotite) but have magnetic rims with visible domain structures (e.g., Sample 139-856H-4R-3, 2-4 cm; 139-856H14R-1, 72-74 cm). An example is shown in Figure 9. Bennett and Graham (1980) observed similar occurrences and attributed this feature to a reaction of the sulfides with air. The amount of monoclinic pyrrhotite increases at the expense of the hexagonal variety if the sulfur content is low, whereas monoclinic pyrrhotite gives way to pyrite at higher sulfur contents. This decrease in the metal/sulfur ratio is caused by the removal of iron to form the oxides. Hexagonal pyr-

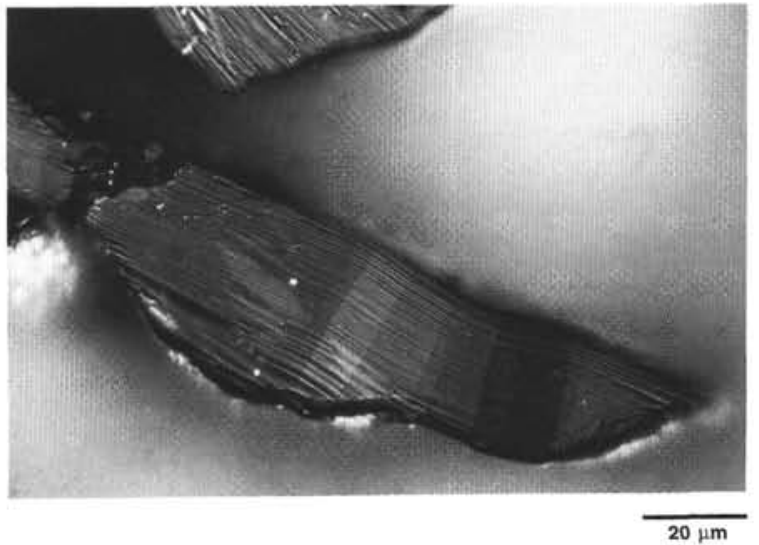

Figure 8. Photomicrograph of polished section from Sample 139-856H-5R-1, $46-48 \mathrm{~cm}$, covered with magnetic colloid and viewed in reflected light. The large multidomain pyrrhotite grain (about $130 \mu \mathrm{m}$ ) has lamellae-shaped domains and long $180^{\circ}$ domain walls.

rhotites with oxidized monoclinic rims may homogenize to a completely hexagonal phase.

\section{Remanence Directions}

Most of the samples from Site 856 were not oriented, so it was impossible to obtain information on the relative age of the sulfides or structural information from the remanent magnetization. AF demagnetization was used to demagnetize the natural remanent magnetization of the five vertically oriented samples. The AF cleaning technique was used because it has no effect on the magnetic mineralogy. 


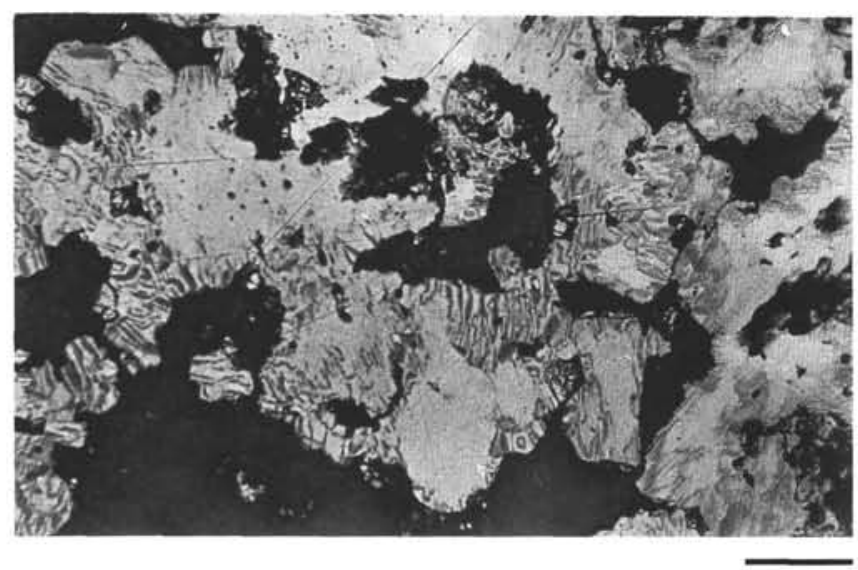

$50 \mu \mathrm{m}$

Figure 9. Photomicrograph of polished section from Sample 139-856H-14R-1, $72-74 \mathrm{~cm}$. The nonmagnetic pyrrhotite grains in the center have rims with visible domain structures.

Three samples containing magnetite as the only magnetic mineral showed stable components with positive inclinations near the expected value of $+66^{\circ} \mathrm{C}$. Progressive demagnetization of the samples containing pyrrhotite did not show a stable component.

\section{SUMMARY}

The magnetic properties of the samples from Hole $856 \mathrm{G}$ are controlled mainly by magnetite and small amounts of hexagonal pyrrhotite. Almost all samples from this hole contain a high pyrite content (up to $90 \%$ ), with magnetite at about $10 \%$, and pyrrhotite (mostly hexagonal pyrrhotite), chalcopyrite, sphalerite, and hematite up to $5 \%$. The high content of magnetite is clearly apparent in the thermomagnetic curves, in rock magnetic parameters determined from the hysteresis loops and in the mineralogical investigations.

Most of the samples from Hole $856 \mathrm{H}$ show magnetic behaviors similar to those of samples from Hole $856 \mathrm{G}$. In these samples magnetization is carried only by magnetite; the pyrrhotite content varies from a trace to $5 \%$. Five samples from Hole $856 \mathrm{H}$ contain predominantly pyrrhotite (monoclinic, as well as hexagonal pyrrhotite up to $75 \%)$ with magnetite between $0 \%$ and $8 \%$. These samples $(-5 R-1$, $46-48 \mathrm{~cm}$; -6R-1, 22-24 cm; -14R-1, 109-111 cm; -15R-1, 109-111 $\mathrm{cm} ;-16 \mathrm{R}-1,84-86 \mathrm{~cm})$ are characterized by high $\mathrm{J}_{\mathrm{rs}} / \mathrm{J}_{\mathrm{s}}\left(0.25<\mathrm{J}_{\mathrm{rs}} / \mathrm{J}_{\mathrm{s}}<\right.$ $0.47)$, and low $B_{c r} / B_{c}$ ratios $\left(1.1<B_{c r} / B_{c}<1.9\right)$. The pyrrhotite grain size estimated from the coercive force and remanent coercive force of the pyrrhotite-controlled samples was between 10 and $50 \mu \mathrm{m}$, which is in good agreement with the observed grain sizes determined by optical microscopy.

\section{ACKNOWLEDGMENTS}

Financial support of Deutsche Forschungsgemeinschaft through grant $\mathrm{He} 1814 / 3-1$ and travel funds from ODP Germany are gratefully acknowledged. I thank B. Herr for considerable help with the rock magnetic measurements. C. Choukér, F. Heider, and H. Chr. Soffel read the manuscript and suggested helpful improvements. The comments of J.G. Rosenbaum, A.T. Fisher, and an unknown reviewer added considerably to the comprehensiveness of the paper.

\section{REFERENCES}

Arnold, R.G., 1962. Equilibrium relations between pyrrhotite and pyrite from $325^{\circ} \mathrm{C}$ to $743^{\circ} \mathrm{C}$. Econ. Geol., 57:72-90.

Abbreviations for names of organizations and publications in ODP reference lists follow
the style given in Chemical Abstracts Service Source Index (published by American Chemical Society).
Bennett, C.E.G., and Graham, J., 1980. New observations on natural pyrrhotites, Part III. Thermomagnetic experiments. Am. Mineral., 65:800-807.

, 1981. New observations on natural pyrrhotites: magnetic transition in hexagonal pyrrhotite. Am. Mineral., 66:1254-1257.

Bin, M., and Pauthenet, R., 1963. Magnetic anisotropy in pyrrhotite. J. Appl. Phys., 34:1161-1162.

Bitter, F., 1931. On inhomogeneities in the magnetization of ferromagnetic materials. Phys. Rev., 38:1903-1905.

Brodskaya, S.Y., Kuz'micheva Y.V., Kutznetzsova, T.V., and Varlamov, V.A., 1976. The magnetic properties of pyrrhotites and the conditions of formation of the Kholodninskoye deposit. Izv. Earth Phys., 6:392-297.

Clark, D.A., 1983. Comments on magnetic petrophysics. Bull. Aust. Soc. Explor Geophys., 14:49-62.

, 1984. Hysteresis properties of sized dispersed monoclinic pyrrhotite grains. Geophys. Res. Lett., 11:173-176.

Davis, E.E., Goodfellow, W.D., Bornhold, B.D., Adshead, J., Blaise, B., Villinger, H., and Le Cheminant, G.M., 1987. Massive sulfides in a sedimented rift valley, northern Juan de Fuca Ridge. Earth Planet. Sci. Lett., 82:49-61.

Davis, E.E., Mottl, M.J., Fisher, A.T., et al., 1992. Proc. ODP, Init. Repts., 139: College Station, TX (Ocean Drilling Program).

Day, R., Fuller, M., and Schmidt, V.A., 1977. Hysteresis properties of titanomagnetites: grain-size and compositional dependence. Phys. Earth Planet. Inter., 13:260-267.

Dekkers, M.J., 1988. Magnetic properties of natural pyrrhotite, Part I: behavior of initial susceptibility and saturation magnetization-related rock-magnetic parameters in a grain-size dependent framework. Phys. Earth Planet. Inter., 52:376-393.

Desborough, G.A., and Carpenter, R.H., 1965. Phase relations of pyrrhotite. Econ. Geol., 60:1431-1450.

Freeman, R., 1986. Magnetic mineralogy of pelagic limestones. Geophys. J. R. Astron. Soc., 85:433-452.

Graham, J., Bennett, C.E.G., and van Riessen, A., 1987. Thermomagnetic behavior and annealing of pyrrhotites containing small quantities of oxygen. Am. Mineral., 72:599-604.

Grommé, C.S., Wright, T.L., and Peck, D.L., 1969. Magnetic properties and oxidation of iron-titanium oxide minerals in Alae and Makaopuhi lava lakes, Hawaii. J. Geophys. Res., 74:5277-5293.

Halgedahl, S.L., and Fuller, M., 1981. The dependence of magnetic domain structure upon magnetization state in polycrystalline pyrrhotite. Phys. Earth Planet. Inter., 26:93-97.

Haraldsen, H., 1941. über die Hochtemperaturumwandlungen der Eisen. IISulfidmischkristalle. Z. Anorg. Allg. Chem., 246:195-226.

Kissin, S.A., and Scott, S.D., 1982. Phase relations involving pyrrhotite below $350^{\circ} \mathrm{C}$. Econ. Geol., 77:1739-1754.

Koski, R.A., Shanks, W.C., III, Bohrson, W.A., and Oscarson, R.L., 1988. The composition of massive sulfide deposits from the sediment-covered floor of Escanaba Trough, Gorda Ridge: implications for depositional processes. Can. Mineral., 26:655-673.

Lonsdale, P., and Becker, K., 1985. Hydrothermal plumes, hot springs, and conductive heat flow in the southern trough of Guaymas Basin. Earth Planet. Sci. Lett., 73:211-225.

Lotgering, F.K., 1956. On the ferrimagnetism of some sulphides and oxides. Philips Res. Rep., 11:190-249.

Menyeh, A., and O'Reilly, W., 1991. The magnetization process in monoclinic pyrrhotite $\left(\mathrm{Fe}_{7} \mathrm{~S}_{8}\right)$ particles containing few domains. Geophys. J. Int., 104:387-399.

Nakazawa, H., and Morimoto, N., 1971. Phase relations and superstructures of pyrrhotite, Fe1-xS. Mat. Res. Bull., 6:345-358.

Petersen, N., and Bleil, U., 1982. Magnetic properties of rocks. In Angenheister, G. (Ed.), Landolt Börnstein, Neue Serie V (Vol. 1b): Heidelberg (Springer-Verlag), 308-365.

Power, L.F., and Fine, H.A., 1976. The iron-sulphur system. Part I. The structures and physical properties of the compounds of the low-temperature phase fields. Miner. Sci. Eng., 8:106-128.

Rochette, P., 1987. Magnetic susceptibility of the rock matrix related to magnetic fabric studies. J. Struct. Geol., 9:1015-1020.

Rochette, P., Fillion, G., Mattéi, J.-L., and Dekkers, M.J., 1989. Magnetic transition at 30-34 Kelvin in pyrrhotite: insight into a widespread occurrence of this mineral in rocks. Earth Planet. Sci. Lett., 98:319-328.

Schwarz, E.J., 1975. Magnetic properties of pyrrhotite and their use in applied geology and geophysics. Pap.-Geol. Surv. Can., 74-59:1-24.

Schwarz, E.J., and Vaughan, D.J., 1972. Magnetic phase relations of pyrrhotite. J. Geomagn. Geoelectr., 24:441-458. 


\section{U. KÖRNER}

Scott, S.D., 1974. Experimental methods in sulfide synthesis. In Ribbe, P.H. (Ed.), Sulfide Mineralogy. Mineral. Soc. Am. Short Course Notes, 1:S-1-38.

Soffel, H.C., 1977. Pseudo-single-domain effects and single-domain multidomain transition in natural pyrrhotite deduced from domain structure observations. J. Geophys., 42:351-359.

, 1981. Domain structure of natural fine grained pyrrhotite in a rock matrix (diabase). Phys. Earth Planet. Inter., 26:98-106.

Thompson, R., and Oldfield, F., 1986. Environmental Magnetism: London (Allen and Unwin).
Ward, J.C., 1970. The structure and properties of some iron sulfides. Rev. Pure Appl. Chem., 20:175-206.

Date of initial receipt: 9 December 1992

Date of acceptance: 16 August 1993

Ms 139SR-243 